\title{
p53 immunostaining is correlated with reduced survival and is not correlated with gene mutations in resected pulmonary large cell carcinomas
}

L.M. Massoni Neto ${ }^{1,5}$, C.P. Bianchi ${ }^{1}$, A.M. Ab' ${ }^{\prime}$ Saber $^{1}$, E.R. Parra ${ }^{1}$, T. Takagaki², J.C. Pereira ${ }^{3}$, F.A. Soares ${ }^{4}$, K. Leite ${ }^{6}$ and V.L. Capelozzi ${ }^{1}$

\author{
1Departamento de Patologia, ${ }^{2}$ Divisão de Moléstias Respiratórias, \\ ${ }^{3}$ Departamento de Cirurgia Torácica, Hospital das Clínicas, \\ Faculdade de Medicina, Universidade de São Paulo, São Paulo, SP, Brasil \\ ${ }^{4}$ Hospital do Cancer A.C. Camargo, São Paulo, SP, Brasil \\ ${ }^{5}$ Hospital Amaral Carvalho, Jaú, SP, Brasil \\ ${ }^{6}$ Biologia Molecular e Genética, Hospital Sírio Libanes, São Paulo, SP, Brasil
}

\author{
Correspondence \\ V.L. Capelozzi \\ Departamento de Patologia \\ Faculdade de Medicina, USP \\ Av. Dr. Arnaldo, 455 \\ 01246-903 São Paulo, SP \\ Brasil \\ Fax: +55-11-3064-2744 \\ E-mail:vcapelozzi@lim05.fm.usp.br \\ Research supported by CNPq \\ (No. 300430/95-7), FAPESP (No. \\ 00/14336-0], and Laboratory of \\ Medical Investigation (LIM-05).
}

Received November 10, 2006 Accepted April 10, 2007

\begin{abstract}
Malignancy of pulmonary large cell carcinomas (LCC) increases from classic LCC through LCC with neuroendocrine morphology (LCCNM) to large cell neuroendocrine carcinomas (LCNEC). However, the histological classification has sometimes proved to be difficult. Because the malignancy of LCC is highly dependent on proteins with functions in the cell cycle, DNA repair, and apoptosis, $p 53$ has been targeted as a potentially useful biological marker. p53 mutations in lung cancers have been shown to result in expression and protein expression also occurs in the absence of mutations. To validate the importance of both $p 53$ protein expression (by immunostaining) and p53 gene mutations in lung LCC (by PCR-single strand conformational polymorphism analysis of exons 5, 6, 7, and 8) and to study their relationships with clinical factors and sub-classification we investigated the correlation of $p 53$ abnormalities in 15 patients with LCC (5 classic LCC, 5 LCNEC, and 5 LCCNM) who had undergone resection with curative intent. Of these patients, $5 / 15$ expressed $p 53$ and none had mutant p53 sequences. There was a negative survival correlation with positive $p 53$ immunostaining $(\mathrm{P}=0.05)$. After adjustment for stage, age, gender, chemotherapy, radiotherapy, and histological subtypes by multivariate analysis, $p 53$ expression had an independent impact on survival. The present study indicates that $p 53$ assessment may provide an objective marker for the prognosis of LCC irrespective of morphological variants and suggests that $p 53$ expression is important for outcome prediction in patients with the early stages of LCC. The results reported here should be considered to be initial results because tumors from only 15 patients were studied: 5 each from LCC, LCNEC and LCCNM. This was due to the rarity of these specific diseases.
\end{abstract}

Key words

- Large cell carcinoma

- p53

- Genetics

- Molecular biology

- Lung cancer

- Mutation analysis ........................... 


\section{Introduction}

Because there is a significant difference in survival time for patients with large cell carcinoma (LCC), Travis et al. (1) recently proposed to subdivide LCC into three subtypes: classic LCC, LCC with neuroendocrine morphology (LCCNM) and large cell neuroendocrine carcinoma (LCNEC), although the LCCNM subtype has not yet been recognized officially in the current WHO classification (2004). Previous reports and data from our group have shown that the malignancy of pulmonary LCC increases in the following order: from classic LCC through LCCNM to LCNEC (2-7). These highly malignant diseases are characterized by rapid and disseminated tumor growth in the majority of patients, and share morphological and functional features (8-11). Since the degree of malignancy of LCC correlates well with histological type, it is essential to be able to distinguish between types. At present, LCC sub-classification depends on the evaluation of histological criteria such as neuroendocrine (NE) morphology, the number of mitoses, the presence or absence of necrosis, and immunohistochemical (IHC) staining $(1,12,13)$. However, these parameters are influenced by different IHC and tissue sampling methods. Therefore, it is often difficult to achieve a specific diagnosis based on available criteria. Among experienced lung pathologists, disagreement commonly occurs when differentiating between LCC lung tumors (14). Thus, it is clear that alternative objective markers are needed to assist in their classification.

Recently, advances in molecular biology and genetics have raised the possibility of new diagnostic techniques and treatment to be applied in clinical oncology for LCC (1520). The results indicate that LCC belongs to a group of non-small cell lung carcinomas, which suggests the possibility that gene abnormalities may be objective markers for the classification of LCC. While genetic analy- sis of LCC has been conducted only very recently, the inactivation of recessive tumor suppressor genes associated with chromosomal deletion, such as $p 53(17 \mathrm{p})$, has been implicated in the genesis of human cancer in a number of studies (21-26). The normal p53 protein has important functions in cell cycle checkpoints and modulates important events such as G1 arrest, DNA repair, and apoptosis (24-26). Alterations in the $p 53$ gene could play crucial roles in the genesis of carcinomas and have been shown to represent one of the most common molecular biological changes in lung carcinomas, including LCC $(25,26)$. More than $85 \%$ of the mutations identified have had their structures determined $(25,26)$. Most mutant p53 proteins produced by missense mutations are resistant to degradation and thus have prolonged half-lives, allowing their detection by IHC staining. Accordingly, many investigators have used this approach as a screening method to identify $p 53$ alterations in tumor samples (25-28). On the other hand, null mutations (complete absence of gene product expression) and nonsense mutations (premature stop codons and shortened protein products) are less common in exons 5-8 but predominate outside these exons, and often may not be detectable by IHC $(26,29-32)$. In addition, protein expression has been described in the absence of mutations $(33,34)$.

Overall, however, published data provide limited comparative information about molecular alterations among the three lung LCC types. A more extensive analysis of LCC at the DNA level is thus warranted to correlate genetic alterations with histological types and patient prognosis. Therefore, to clarify the relationship between $p 53 \mathrm{mu}-$ tations, especially the type of mutation, and IHC staining as well as prognosis, we have investigated both $p 53$ protein expression (by IHC) and $p 53$ gene mutations by polymerase chain reaction-single strand conformational polymorphism (PCR-SSCP) analysis of exons 5, 6, 7, and 8 (35). 


\section{Patients and Methods}

Tumor samples and clinicopathological data

p53 alterations were examined in a series of 15 LCC ( 5 classic LCC, 5 LCNEC and 5 LCCNM) that were not accompanied by other primary malignancies and were resected consecutively from 1982 to 2002 at the University Hospital, University of São Paulo. The 15 patients included 11 men and 4 women, and the median patient age at surgery was 58 years (range: $38-75$ years; Table 1). All 15 patients had full-preoperative tumor staging ( $\mathrm{T}$ stage), and were considered to have potentially curable tumors by surgical resection. However, after pathological evaluation when more lymph nodes were sampled (N stage), 4 patients were in N1 final stage, with the remaining 11 patients in N0. Postoperative pathological final staging ( $\mathrm{P}$ stage) resulted in 9 stage I cases and 6 stage II cases. For survival analysis, the median complete follow-up time was 18 months (range: 3 to 43 months). All patients underwent postoperative chemotherapy (scheme 1 (until 1985) - cyclophosphamide; scheme 2 (after 1985) - cisplatin + vincristine + mitomycin), 5 of them with associated radiotherapy. The major criteria for adjuvant therapy were the anaplastic or NE phenotype and the aggressive nature of the disease. No standardized adjuvant treatment protocol was followed because there was a long interval between the first and the last cases, with a correspondingly broad variation of protocols used within this period.

Tumor tissue samples were obtained at surgical treatment of LCC and fixed in $10 \%$ formalin. For each case, one or two slides of the main tumor were selected by light microscopy. Acceptable sections were those that represented the predominant histological pattern of LCC identified in the majority of slides, with at least 10 microscopic fields at a magnification of $250 \mathrm{X}$. Their respective paraffin-embedded blocks were sectioned at
$3 \mu \mathrm{m}$ and stained with hematoxylin and eosin. Two pathologists (AMA and VLC) reviewed these slides separately in an independent and blind fashion and agreed with the previous histological criteria for the diagnosis of LCC. To minimize discrepancies, the criteria evaluated for tumor classification were agreed upon during a series of preliminary discussions between the two pathologists and after informal review of the cases.

The 15 tumors were classified either as LCNEC or LCCNM if there was evidence of all of the following: 1) NE morphology, such as organoid nesting, palisading rosettes, and trabeculae, 2) a high mitotic rate of $\geq 11$ per $2 \mathrm{~mm}^{2}$ (10 high-power fields), 3) necrosis (often a large zone), 4) cytological features of a non-small cell carcinoma, i.e., large cell size, low nuclear to cytoplasmic ratio, vesicular or fine chromatin, and/or frequent nucleoli (Figure 1A-C). LCC without NE morphology were classified as classic LCC. Thus, we examined and compared the clinicopathological and biological differences of classic LCC, LCNEC, and LCCNM.

The distinction between LCNEC and LCCNM was obtained by NE immunoexpression, which is positive for LCNEC, but negative for LCCNM. To detect NE immunoexpression (1-3), we used a polyclonal anti-chromogranin antibody (Dako A/S, Glostrup, Denmark) at 1:1,600 dilution and a monoclonal anti-synaptophysin antibody (Dako) at 1:100 dilution. Examples of tumor staining for chromogranin and synaptophysin are illustrated in Figure 1D.

\section{p53 mutation analysis}

DNA extraction. DNA was extracted from three $10-\mu \mathrm{m}$ sections of the paraffin block that best represented each tumor (previously selected from hematoxylin and eosin-stained slides). Disposable microtome blades were used, and instruments were cleaned with xylene after each tissue section to avoid 
cross-contamination. Three baths in $500 \mu \mathrm{L}$ xylene at $95^{\circ} \mathrm{C}$ followed by three baths in $500 \mu \mathrm{L} 99 \%$ ethanol were used to dewax the tissue. Next, the tissue samples were centrifuged for $5 \mathrm{~min}$ at $13,000 \mathrm{rpm}$ and $4^{\circ} \mathrm{C}$. The resulting pellets were incubated overnight at $37^{\circ} \mathrm{C}$ in $500-\mu \mathrm{L}$ digestion buffer $(10 \mathrm{mM}$ Tris, pH 7.4, $100 \mathrm{mM} \mathrm{NaCl}, 25 \mathrm{mM}$ disodium EDTA, $0.5 \%$ sodium dodecyl sulfate) containing $10 \mu \mathrm{L}$ proteinase $\mathrm{K}(200 \mu \mathrm{g} / \mathrm{mL}$ final concentration). The enzyme was inactivated by heating the specimens for $10 \mathrm{~min}$ at $95^{\circ} \mathrm{C}$, protein was removed by adding an equal volume of phenol:chloroform:isoamyl alcohol (25:24:1), and nucleic acid was precipitated from the aqueous phase by adding $1 / 4$ volume of $8 \mathrm{nM}$ ammonium acetate and an equal volume of isopropanol. The nucleic acid samples were then incubated at $-20^{\circ} \mathrm{C}$ for $1 \mathrm{~h}$ and centrifuged for $10 \mathrm{~min}$ at 13,000
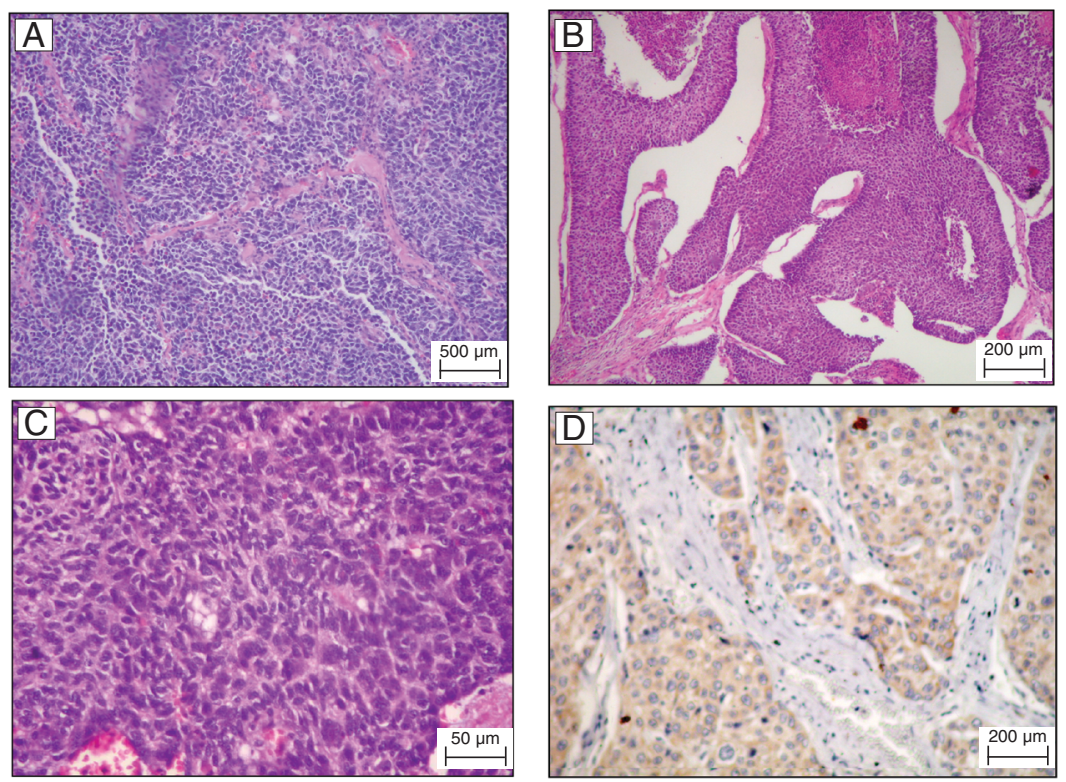

Figure 1. Histological patterns of large cell carcinomas. Panel $A$ shows the classical large cell carcinoma (LCC), a large cell tumor with clearly visible nucleoli, lower nuclear-cytoplasmic ratio and absence of neuroendocrine features (hematoxylin and eosin, 100X). Panels $B$ and $C$ show neuroendocrine morphology in LCC with organoid nesting, palisading, and rosettes. Numerous mitoses are seen in LCC with neuroendocrine morphology (B). Cytologic features in large cell neuroendocrine carcinoma include large cell size, fine chromatin and clearly visible nucleoli (C; hematoxylin and eosin, Panel B 40X and Panel C 400X). Panel $D$ shows an immunohistochemistry reaction (magnification 200X) with tumor cells stained for antichromogranin A antibody and only large cell neuroendocrine carcinoma tumors stained for chromogranin. rpm and $4^{\circ} \mathrm{C}$. The resulting pellets were washed in $70 \%$ ethanol for salt removal, air dried, and resuspended in $50 \mu \mathrm{L}$ TE/RNAse (36).

\section{Polymerase chain reaction amplification}

The PCR amplification and non-isotopic detection of exons 5 to 8 of the $p 53$ gene were described by Soong and Iacopetta (37) and will be summarized here. The PCR assays were carried out in $25-\mu \mathrm{L}$ reaction buffer containing $0.2 \mathrm{mM}$ deoxynucleotide triphosphates, $2.5 \mathrm{mM}$ magnesium chloride, each primer at a concentration of $0.4 \mu \mathrm{M}, 0.25$ units Taq polymerase, and $1 \mu \mathrm{L}$ extracted DNA. Thirty-five thermal cycles of $30 \mathrm{~s}$ at $94^{\circ} \mathrm{C}, 1 \mathrm{~min}$ at $60^{\circ} \mathrm{C}$, and $1 \mathrm{~min}$ at $72^{\circ} \mathrm{C}$ were completed, and the cycling was concluded by a 10 -min extension at $72^{\circ} \mathrm{C}$, all in a thermocycler Gene Amp PCR System 2400 (Perkin Elmer, Foster City, CA, USA). Procedures to prevent contamination were followed.

Single-strand conformational polymorphism screening for p53 mutations

Single-stranded DNA for SSCP analysis was produced by combining equal $5-\mu \mathrm{L}$ volumes of PCR product and formamide loading buffer $(95 \%$ formamide, $10 \mathrm{mM}$ EDTA, $0.05 \%$ bromophenol blue, $0.05 \%$ xylene cyanol) and heating at $95^{\circ} \mathrm{C}$ for $10 \mathrm{~min}$. The DNA was subjected to electrophoresis at $200 \mathrm{~V}$ for $2 \mathrm{~h}$ at $4^{\circ} \mathrm{C}$ within a Mighty-small apparatus (Pharmacia, Uppsala, Sweden) containing $15 \%$ polyacrylamide gel with $5 \%$ glycerol. Silver staining was done by the method of Bassam et al. (38). The gels were soaked for $5 \mathrm{~min}$ in $10 \%$ ethanol, $5 \mathrm{~min}$ in $1 \%$ nitric acid, and $10 \mathrm{~min}$ in an impregnating solution $(0.1 \mathrm{~g}$ silver nitrate and $150 \mu \mathrm{L}$ formaldehyde in $100 \mathrm{~mL}$ water), then soaked in a developing solution ( $3 \mathrm{~g}$ sodium carbonate, $150 \mu \mathrm{L}$ formaldehyde, and $100 \mu \mathrm{L}$ sodium sulfate in $100 \mathrm{~mL}$ water) until bands 
were visible, and then fixed in $10 \%$ acetic acid for $5 \mathrm{~min}$. The gels were analyzed under white light with a computerized imaging system (gel Doc 1000, BioRad, North Ryde, Australia) and compared with wild-type $p 53$ samples from normal tissue extracted and amplified by the same methods to detect $p 53$ mutations, which would appear as extra bands or mobility shifts.

\section{p53 protein analysis}

The presence of $p 53$ protein was detected by IHC staining using the avidin-biotin immunoperoxidase complex technique, pressure-cooking antigen retrieval, biotinylated rabbit antimouse IgG (Dako; dilution 1:400) streptavidin combined in vitro with biotinylated horseradish peroxidase (Dako; dilution 1:1000), diaminobenzidine tetrahydrochloride, and hematoxylin counterstaining. The antibody used was mouse monoclonal antihuman p53 protein (DO7; Dako; dilution $1: 40$ ), whose specificity and sensitivity in non-small cell lung cancer vary from 35 to $75 \%$ and from 75 to $100 \%$, respectively (2528). Brownish nuclear staining was considered to be evidence of $p 53$ antigen expression by cells. In addition, we quantified the staining as follows. First, we selected the region with the highest expression at low magnification. Then, at 400X, we used an eyepiece coupled to a systematic point-sampling grid with 100 points and 50 lines to count the fraction of points overlaying positively stained structures and we averaged this over 10 microscopic fields to obtain a percentage of the resulting stained structures $(39,40)$.

\section{Statistical analysis}

To assess any correlations between frequencies or types of mutation, immunohistochemistry and clinicopathological data, Pearson chi-square and independent-sample $t$-test procedures were used, with $\mathrm{P}<0.05$ indicating a significant difference. Survival curves were created by the Kaplan-Meier method, and the statistical significance of differences was calculated by the log-rank test. Multivariate analyses were performed to identify independent prognostic factors and to assess the relative risk using the Cox proportional hazards model with the Statistical Package for Social Science (Norusis MJ, SPSS for Windows (10.0), Chicago, IL, USA, SPSS Inc.; 2002). In this model, seven factors potentially related to survival (age at surgery, sex, histology, P stage, chemotherapy, radiotherapy, and $p 53$ status) were included, and the model selection to identify the subset of significant variables was based on the stepwise method for backward selection.

\section{Results}

\section{p53 mutation}

No mutations were detected; electrophoresis of the amplified products of exons 5, 6 , 7 , and 8 of the $p 53$ gene revealed no abnormalities of band migration in any of the 15 cases studied (Figure 2A-D).
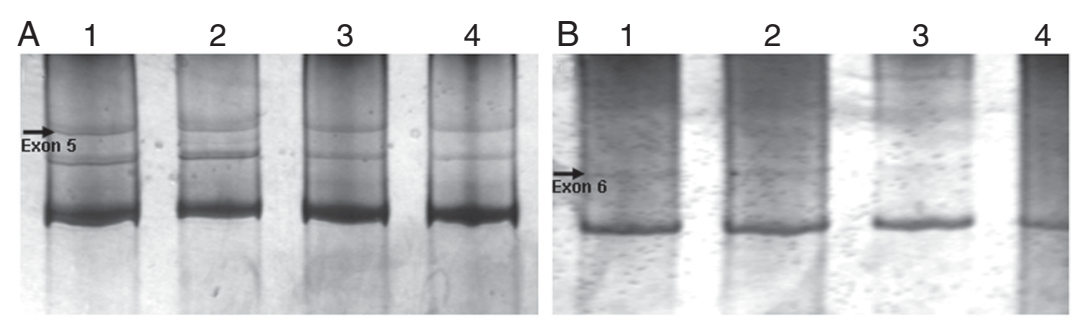

C

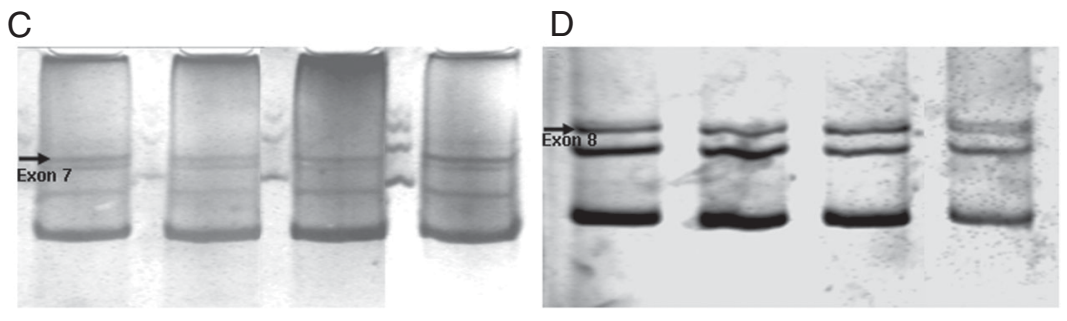

Figure 2. Panels $A$ to $D$ show electrophoresis of the amplified products of exons $5,6,7$, and 8 of the p53 gene, respectively, which revealed no abnormalities of band migration in any of the 15 cases studied in lanes 1,2 , and 3 of tumors and lane 4 of normal tissue. 
Table 1. Characteristics of patients with resected large cell pulmonary carcinomas.

\begin{tabular}{|c|c|c|c|}
\hline & p53 negative & p53 positive & Total \\
\hline Number of cases & 10 & 5 & 15 \\
\hline Age (years) & $58(38-75)$ & $55(50-63)$ & $56(38-75)$ \\
\hline \multicolumn{4}{|l|}{ Gender } \\
\hline Male & $8(53.3 \%)$ & $3(20 \%)$ & $11(73.3 \%)$ \\
\hline Female & $2(13.3 \%)$ & $2(13.3 \%)$ & $4(26.7 \%)$ \\
\hline \multicolumn{4}{|l|}{ P stage } \\
\hline I & $6(40 \%)$ & $3(20 \%)$ & $9(60 \%)$ \\
\hline II & $4(26.7 \%)$ & $2(13.3 \%)$ & $6(40 \%)$ \\
\hline III & 0 & 0 & 0 \\
\hline \multicolumn{4}{|l|}{$\mathrm{N}$ stage } \\
\hline No & $7(46.7 \%)$ & $4(26.6 \%)$ & $11(73.3 \%)$ \\
\hline N1 & $3(20 \%)$ & $1(6.7 \%)$ & $4(26.7 \%)$ \\
\hline N2 & 0 & 0 & 0 \\
\hline N3 & 0 & 0 & 0 \\
\hline \multicolumn{4}{|l|}{ T stage } \\
\hline $\mathrm{T} 1$ & $3(20 \%)$ & $4(26.7 \%)$ & $7(46.7 \%)$ \\
\hline $\mathrm{T} 2$ & $7(46.7 \%)$ & $1(6.6 \%)$ & $8(53.3 \%)$ \\
\hline T3 & 0 & 0 & 0 \\
\hline $\mathrm{T} 4$ & 0 & 0 & 0 \\
\hline \multicolumn{4}{|l|}{ Histological subtypes } \\
\hline LCC & $4(26.7 \%)$ & $1(6.7 \%)$ & $5(33.3 \%)$ \\
\hline LCNEC & $3(20 \%)$ & $1(13.3 \%)$ & $5(33.3 \%)$ \\
\hline LCCNM & $3(20 \%)$ & $1(13.3 \%)$ & $5(33.3 \%)$ \\
\hline Radiotherapy & 7 (46.7\%) & $3(20 \%)$ & $10(66.7 \%)$ \\
\hline Chemotherapy & $10(66.7 \%)$ & $5(33.3 \%)$ & $15(100 \%)$ \\
\hline Follow-up (months) & $18(3-42)$ & $18(4-43)$ & $18(3-43)$ \\
\hline Overall survival (months) & $12.6(3-42)$ & $12.8(4-43)$ & $12(3-43)$ \\
\hline
\end{tabular}

Data reported as median (range) or number with percent of total in parentheses. $P$ stage $=$ postoperative pathological final staging; $\mathrm{N}$ stage $=$ lymph node sampled after pathological evaluation: $T$ stage $=$ preoperative tumor staging; $L C C=$ large cell carcinoma; LCNEC = large cell neuroendocrine carcinoma; LCCNM = large cell carcinoma with neuroendocrine morphology.

Table 2. Histological subtypes and results of $p 53$ expression and mutation.

\begin{tabular}{lccl}
\hline Histological subtypes & \multicolumn{2}{c}{$p 53$ expression } & \multirow{2}{*}{ p53 mutation } \\
\cline { 2 - 3 } & Mean & Range & \\
\hline LCC & 9.3 & $0-46.50$ & No mutation \\
LCNEC & 14.96 & $0-61.70$ & No mutation \\
LCCNM & 21.28 & $0-80$ & No mutation
\end{tabular}

The unit of $p 53$ expression "\% of points" indicates the number of points overlying the phenomena of interest divided by the total number of points overlying the tumor. For abbreviations, see legend to Table 1.

\section{p53 expression and relationship with clinicopathological parameters}

Tables 1 and 2 show clinicopathological parameters. Five cases $(33.3 \%)$ were positive for $p 53$. Among the positive cases, immunostaining was present in more than $60 \%$ of the cells in 3 cases ( 2 LCNEC and 1 LCCNM). Tumors of male patients younger than 65 years tended to be more $p 53$-positive $(\mathrm{P}=0.01)$. No statistically significant relationship was demonstrated between $p 53$ and $\mathrm{N}$ stage or T stage.

\section{Survival and p53 status}

Examination of the relationships between $p 53$ expression by the cut-off point of $60 \%$ positive selected taking into account the value above the median and overall survival, using the Kaplan-Meier method and the log-rank test, revealed a shorter survival period for the 2 LCC patients with $p 53$ expression higher than $60 \%$ compared to those with lower expression. This number was obtained by the median value of $p 53$ expression in the subtypes and adopted as cut-off. The median survival for patients with p53 expression higher than $60 \%$ was 4 and 24 months for patients with $p 53$ expression lower than $60 \%$ and this difference was statistically significant $(\mathrm{P}=0.02$; Figure 3$)$. We also found that the prognostic information provided by $p 53$ was maximized when this variable was used as the continuous one (likelihood ratio $=$ 48.31), that is, one without the usual cut-off point at $60 \%$ of the tumor tissue (likelihood ratio $=36.87$ ). There was no difference in survival at the $\mathrm{N}$ stage, $\mathrm{P}$ stage, $\mathrm{T}$ stage, and histological types (classic LCC, LCNEC, and LCCNM).

Multivariate analysis of age, sex, histology, P stage, chemotherapy scheme, radiotherapy, and the immunoexpression of $p 53$ was performed to examine the interrelationship of possible prognostic factors and survival (Table 3). In all cases, p53 immunoex- 
pression was an independent prognostic factor with statistical significance, predicting poor survival for $\mathrm{P}$ stage II patients with a relative risk of $16.103(\mathrm{P}=0.05$; Table 3$)$.

\section{Discussion}

In the present study we determined $p 53$ protein expression by IHC and looked for mutations in $p 53$ exons $5,6,7$, and 8 by PCR-SSCP analysis in 15 specimens of resected LCC (classic LCC, LCNEC, and LCCNM). The series is small because LCC of the lung are rare, representing approximately $9 \%$ of all lung cancers in most studies.

Although we did not detect $p 53$ mutations in our 15 cases of localized LCC, IHC staining indicated that $p 53$ protein was expressed in 5 of the 15 tumors (33.3\%). Among these tumors, the histological types LCNEC and LCCNM presented the same expression. A possible explanation for this low frequency of mutations is due to the small number of tumors included in each category and the rarity of these tumors. In our study and in most of the other studies in the literature with low-p53 mutation rates (26,29-32), exons 5 through 8 were examined. However, when primers to amplify the region extending from exons 4 to 8 and exon 11 ( 9 and 10 not analyzed) were used to evaluate a series of 144 localized non-small cell lung carcinomas (107 adenocarcinomas and 37 squamous cell carcinomas) (33) p53 mutations were found in $45 \%$ of the cases, suggesting that exons 4 and 11 ought to be evaluated in addition to exons 5 through 8 .

To interpret our results, it is important to understand the situations that can cause a tumor to be $p 53$ positive or $p 53$ negative by IHC. As mentioned before, $p 53$ normally has too short a half-life to be detected by IHC (35). Mutations are the most common p53 mutations, and because they stabilize p53 protein, they are detected by IHC (35). Nonsense or frame shift mutations, gene

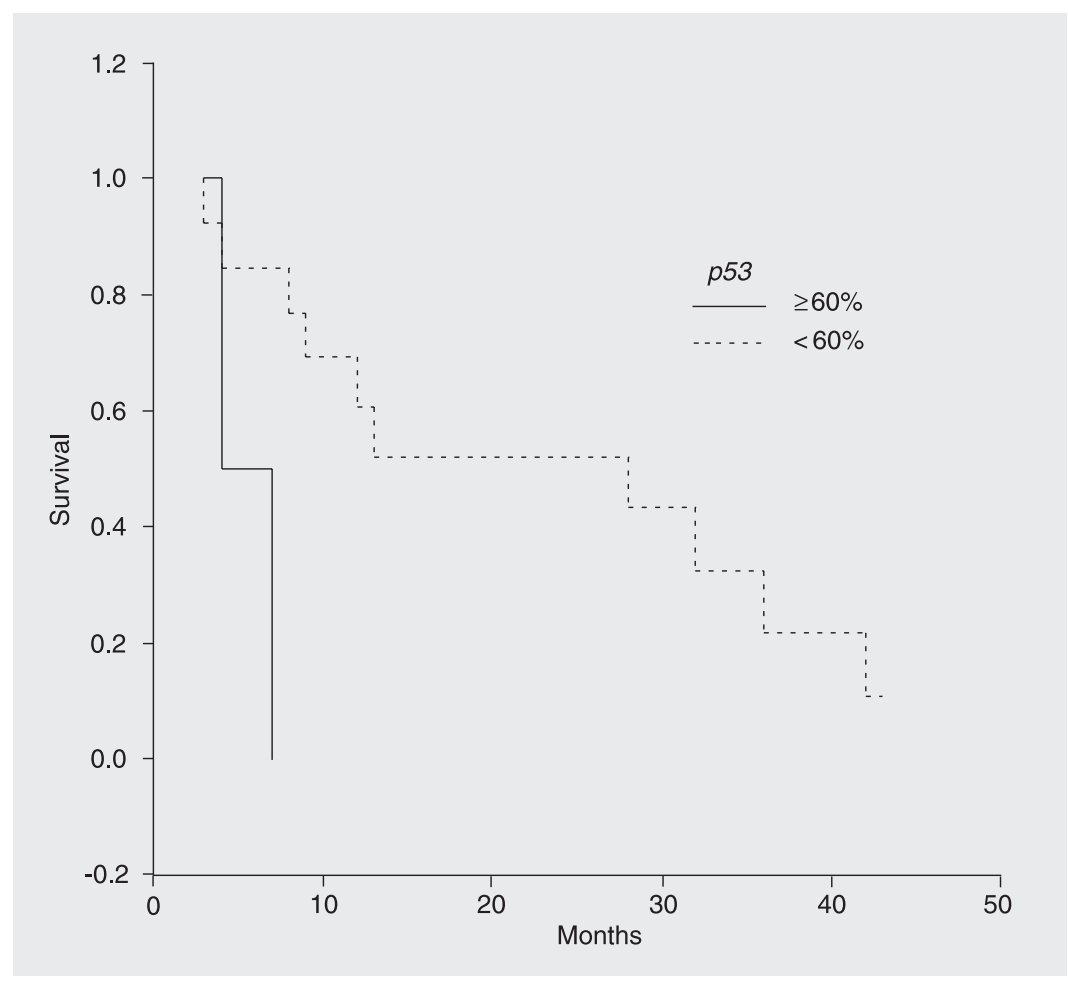

Figure 3. Kaplan-Meier overall survival curves of patients with resected pulmonary large cell carcinomas show that the amount of $p 53$ immunoexpression is inversely related to survival. $>60 \%$ indicates that more than $60 \%$ of the tumor cell structure reacted with monoclonal antibodies to $p 53$. The $>60 \%$ group contained tumors from 2 patients and the $<60 \%$ group consisted of tumors from 13 patients. Fifteen patients were $p 53$ negative and are included in the $<60 \%$ group.

Table 3. Cox proportional hazard model analysis of survival time.

\begin{tabular}{|c|c|c|c|c|c|c|}
\hline \multirow[t]{2}{*}{ Variables } & \multirow[t]{2}{*}{ Coefficient B } & \multirow[t]{2}{*}{ SEM } & \multirow[t]{2}{*}{$\mathrm{P}$} & \multirow[t]{2}{*}{$\operatorname{Exp}(B)$} & \multicolumn{2}{|c|}{$95 \% \mathrm{Cl}$ for $\operatorname{Exp}(\mathrm{B}$} \\
\hline & & & & & Lower & Upper \\
\hline Female gender & r $\quad-0.704$ & 1.044 & 0.500 & 0.495 & 0.64 & 3.824 \\
\hline Age & -0.517 & 1.148 & 0.652 & 0.596 & 0.063 & 5.652 \\
\hline P stage II & -1.602 & 1.528 & 0.294 & 0.201 & 0.010 & 4.023 \\
\hline \multicolumn{7}{|l|}{ Histology } \\
\hline LCNEC & -1.043 & 0.990 & 0.291 & 0.352 & 0.051 & 2.452 \\
\hline LCCNM & 0.181 & 1.104 & 0.870 & 1.198 & 0.138 & 10.431 \\
\hline $\mathrm{CHT}$ & - & - & - & - & - & - \\
\hline $\mathrm{RT}$ & -0.393 & 1.098 & 0.836 & 0.675 & 0.16 & 27.887 \\
\hline$p 53>60 \%$ & 2.779 & 1.416 & 0.05 & 16.103 & 1.003 & 256.563 \\
\hline
\end{tabular}

SEM = standard error of the mean; Exp = risk; LCNEC = large cell neuroendocrine carcinoma; LCCNM = large cell carcinoma with neuroendocrine morphology; CHT = chemotherapy; $\mathrm{RT}$ = radiotherapy. 
deletions, and mutations that cause truncation of the protein may not be detected by IHC. The IHC method can also detect p53 that has been temporarily stabilized by some mechanism other than mutation (25). Stabilized $p 53$ that is detected by the IHC method is inactive and does not normally function in the control of cell cycle and apoptosis induction (35).

Our results confirmed other reports that LCC and its variants LCNEC and LCCNM have a high frequency of $p 53$ expression but are not correlated with gene mutations (1921,23). Moreover, $p 53$ mutations occurred at the same frequency in LCC, LCNEC and LCCNM. Inactivating $p 53$ mutations (mostly missense mutations) are detected in up to $50 \%$ of LCC (31). These findings suggest that since LCC is a poorly differentiated tumor originating from the same stem cells, it should share the molecular and genetic alterations of their variants LCNEC and LCCNM (22) when exposed to the same carcinogens.

Reported clinical prognostic criteria for LCC are not different from those for other non-small cell lung cancers. The major criteria are performance status at diagnosis and the disease extension reflected by tumor, node, metastasis, and stage. However, in the present study, we found a negative survival correlation with positive $p 53$ immunostaining. These findings suggest that expression of $p 53$ protein determined by immunostaining may contribute to an adverse outcome due to the ability of $p 53$ to act as a dominant oncogene, or alternatively, that $p 53$ expression may reflect ongoing DNA damage in the tumor as a marker of a more aggressive behavior. When adjusted for stage, age, gender, and histological subtypes by multivariate analysis, there was an independent impact of $p 53$ expression on survival.

The present study indicated that assessment of p53 could provide an objective marker that can distinguish LCC prognosis irrespective of morphological variants. These data also suggest that $p 53$ expression and absence of gene mutations are important for outcome prediction in patients with early stages of LCC. The results reported here should be considered to be initial results because tumors from only 15 patients were studied: 5 each from LCC, LCNEC and LCCNM. This was due to the rarity of these specific diseases.

\section{References}

1. Travis WD, Brambilla E, Muller-Hermelink HC, Harris CC. Pathology and genetics - Tumors of the lung, pleura, thymus and heart. The histological typing of lung and pleural tumors. WHO classification of tumors. 4th edn. Lyon: IARC Press; 2004.

2. Delmonte VC, Alberti O, Saldiva PH. Large cell carcinoma of the lung. Ultrastructural and immunohistochemical features. Chest 1986; 90: 524-527.

3. Travis WD, Linnoila RI, Tsokos MG, Hitchcock CL, Cutler GB Jr, Nieman L, et al. Neuroendocrine tumors of the lung with proposed criteria for large-cell neuroendocrine carcinoma. An ultrastructural, immunohistochemical, and flow cytometric study of 35 cases. Am J Surg Pathol 1991; 15: 529-553.

4. Dresler CM, Ritter JH, Patterson GA, Ross E, Bailey MS, Wick MR. Clinical-pathologic analysis of 40 patients with large cell neuroendocrine carcinoma of the lung. Ann Thorac Surg 1997; 63: 180-185.

5. Garcia-Yuste M, Matilla JM, Alvarez-Gago T, Duque JL, Heras F, Cerezal LJ, et al. Prognostic factors in neuroendocrine lung tumors: a Spanish Multicenter Study. Spanish Multicenter Study of Neuroendocrine Tumors of the Lung of the Spanish Society of Pneumology and Thoracic Surgery (EMETNE-SEPAR). Ann Thorac Surg 2000; 70: 258-263.

6. Wick MR, Berg LC, Hertz MI. Large cell carcinoma of the lung with neuroendocrine differentiation. A comparison with large cell "undifferentiated" pulmonary tumors. Am J Clin Pathol 1992; 97: 796-805.

7. Iyoda A, Hiroshima K, Toyozaki T, Haga Y, Fujisawa T, Ohwada H. Clinical characterization of pulmonary large cell neuroendocrine carcinoma and large cell carcinoma with neuroendocrine morphology. Cancer 2001; 91: 1992-2000.

8. Iyoda A, Hiroshima K, Baba M, Saitoh Y, Ohwada H, Fujisawa T. Pulmonary large cell carcinomas with neuroendocrine features are high-grade neuroendocrine tumors. Ann Thorac Surg 2002; 73 : 1049-1054.

9. Zacharias J, Nicholson AG, Ladas GP, Goldstraw P. Large cell neuroendocrine carcinoma and large cell carcinomas with neuroendocrine morphology of the lung: prognosis after complete resection and systematic nodal dissection. Ann Thorac Surg 2003; 75: 348-352.

10. Ab' Saber AM, Massoni Neto LM, Bianchi CP, Ctenas BB, Parra ER, Eher EM, et al. Neuroendocrine and biologic features of primary 
tumors and tissue in pulmonary large cell carcinomas. Ann Thorac Surg 2004; 77: 1883-1890.

11. Kobayashi $Y$, Tokuchi $Y$, Hashimoto $T$, Hayashi $M$, Nishimura $H$, Ishikawa $Y$, et al. Molecular markers for reinforcement of histological subclassification of neuroendocrine lung tumors. Cancer Sci 2004; 95: 334-341.

12. Travis WD, Rush W, Flieder DB, Falk R, Fleming MV, Gal AA, et al. Survival analysis of 200 pulmonary neuroendocrine tumors with clarification of criteria for atypical carcinoid and its separation from typical carcinoid. Am J Surg Pathol 1998; 22: 934-944.

13. Beasley MB, Thunnissen FB, Brambilla E, Hasleton $P$, Steele $R$, Hammar SP, et al. Pulmonary atypical carcinoid: predictors of survival in 106 cases. Hum Pathol 2000; 31: 1255-1265.

14. Travis WD, Gal AA, Colby TV, Klimstra DS, Falk R, Koss MN. Reproducibility of neuroendocrine lung tumor classification. Hum Pathol 1998; 29: 272-279.

15. Howe MC, Chapman A, Kerr K, Dougal M, Anderson H, Hasleton PS. Neuroendocrine differentiation in non-small cell lung cancer and its relation to prognosis and therapy. Histopathology 2005; 46: 195201.

16. Peng WX, Sano T, Oyama T, Kawashima O, Nakajima T. Large cell neuroendocrine carcinoma of the lung: a comparison with large cell carcinoma with neuroendocrine morphology and small cell carcinoma. Lung Cancer 2005; 47: 225-233.

17. Hiroshima K, lyoda A, Shibuya K, Haga Y, Toyozaki T, lizasa T, et al. Genetic alterations in early-stage pulmonary large cell neuroendocrine carcinoma. Cancer 2004; 100: 1190-1198.

18. Jones MH, Virtanen C, Honjoh D, Miyoshi T, Satoh Y, Okumura S, et al. Two prognostically significant subtypes of high-grade lung neuroendocrine tumours independent of small-cell and large-cell neuroendocrine carcinomas identified by gene expression profiles. Lancet 2004; 363: 775-781.

19. de Lange R, Dimoudis N, Weidle UH. Identification of genes associated with enhanced metastasis of a large cell lung carcinoma cell line. Anticancer Res 2003; 23: 187-194.

20. Ullmann R, Petzmann S, Sharma A, Cagle PT, Popper HH. Chromosomal aberrations in a series of large-cell neuroendocrine carcinomas: unexpected divergence from small-cell carcinoma of the lung. Hum Pathol 2001; 32: 1059-1063.

21. Petersen I, Langreck H, Wolf G, Schwendel A, Psille R, Vogt P, et al. Small-cell lung cancer is characterized by a high incidence of deletions on chromosomes 3p, 4q, 5q, 10q, 13q and 17p. Br J Cancer 1997; 75: 79-86.

22. Gugger M, Burckhardt E, Kappeler A, Hirsiger H, Laissue JA, Mazzucchelli L. Quantitative expansion of structural genomic alterations in the spectrum of neuroendocrine lung carcinomas. J Pathol 2002; 196: 408-415.

23. Onuki N, Wistuba II, Travis WD, Virmani AK, Yashima K, Brambilla $\mathrm{E}$, et al. Genetic changes in the spectrum of neuroendocrine lung tumors. Cancer 1999; 85: 600-607.

24. Lane DP. Cancer. p53, guardian of the genome. Nature 1992; 358: 15-16.

25. Harris CC, Hollstein M. Clinical implications of the p53 tumor-sup- pressor gene. N Engl J Med 1993; 329: 1318-1327.

26. Greenblatt MS, Bennett WP, Hollstein M, Harris CC. Mutations in the p53 tumor suppressor gene: clues to cancer etiology and molecular pathogenesis. Cancer Res 1994; 54: 4855-4878.

27. Takahashi T, Nau MM, Chiba I, Birrer MJ, Rosenberg RK, Vinocour $M$, et al. p53: a frequent target for genetic abnormalities in lung cancer. Science 1989; 246: 491-494.

28. Iggo R, Gatter K, Bartek J, Lane D, Harris AL. Increased expression of mutant forms of p53 oncogene in primary lung cancer. Lancet 1990; 335: 675-679.

29. Hartmann A, Blaszyk H, McGovern RM, Schroeder JJ, Cunningham $\mathrm{J}$, De Vries EM, et al. p53 gene mutations inside and outside of exons 5-8: the patterns differ in breast and other cancers. Oncogene 1995; 10: 681-688.

30. Casey G, Lopez ME, Ramos JC, Plummer SJ, Arboleda MJ, Shaughnessy $M$, et al. DNA sequence analysis of exons 2 through 11 and immunohistochemical staining are required to detect all known p53 alterations in human malignancies. Oncogene 1996; 13: 1971-1981.

31. Bodner SM, Minna JD, Jensen SM, D'Amico D, Carbone D, Mitsudomi T, et al. Expression of mutant p53 proteins in lung cancer correlates with the class of p53 gene mutation. Oncogene 1992; 7: 743-749.

32. Leite KR, Franco MF, Srougi M, Nesrallah LJ, Nesrallah A, Bevilacqua RG, et al. Abnormal expression of MDM2 in prostate carcinoma. Mod Pathol 2001; 14: 428-436.

33. Hashimoto T, Tokuchi $\mathrm{Y}$, Hayashi M, Kobayashi $\mathrm{Y}$, Nishida K, Hayashi S, et al. p53 null mutations undetected by immunohistochemical staining predict a poor outcome with early-stage non-small cell lung carcinomas. Cancer Res 1999; 59: 5572-5577.

34. Carbone DP, Mitsudomi T, Chiba I, Piantadosi S, Rusch V, Nowak $\mathrm{JA}$, et al. p53 immunostaining positivity is associated with reduced survival and is imperfectly correlated with gene mutations in resected non-small cell lung cancer. A preliminary report of LCSG 871. Chest 1994; 106: 377S-381S.

35. Bosari S, Viale G. The clinical significance of p53 aberrations in human tumours. Virchows Arch 1995; 427: 229-241.

36. Wright DK, Mano MM. Sample preparation from paraffin-embedded tissues. In: Innis M (Editor), PCR protocols: a guide to methods and applications. San Diego: Academic Press; 1990. p 153.

37. Soong R, lacopetta BJ. A rapid and nonisotopic method for the screening and sequencing of p53 gene mutations in formalin-fixed, paraffin-embedded tumors. Mod Pathol 1997; 10: 252-258.

38. Bassam BJ, Caetano-Anolles G, Gresshoff PM. Fast and sensitive silver staining of DNA in polyacrylamide gels. Anal Biochem 1991; 196: 80-83.

39. Gundersen HJ, Bendtsen TF, Korbo L, Marcussen N, Moller A, Nielsen $\mathrm{K}$, et al. Some new, simple and efficient stereological methods and their use in pathological research and diagnosis. APMIS 1988; 96: 379-394.

40. Hilliard JE. Measurements of volume in volume. In: DeHoff R, Rhines FN (Editors), Quantitative microscopy. New York: McGraw-Hill Book Co.; 1968. p 48-49. 